\title{
YIELD OF FOUR Agaricus bisporus STRAINS IN THREE COMPOST FORMULATIONS AND CHEMICAL COMPOSITION ANALYSES OF THE MUSHROOMS
}

\author{
Meire Cristina Nogueira de Andrade ${ }^{1}$; Diego Cunha Zied ${ }^{1}$; Marli Teixeira de Almeida Minhoni ${ }^{2 *}$; \\ João Kopytowski Filho ${ }^{1}$ \\ ${ }^{1}$ Instituto Nacional de Pesquisas da Amazônia, Coordenação de Pesquisas em Produtos Florestais, Manaus, AM, Brasil; \\ ${ }^{2}$ Departamento de Produção Vegetal, Universidade Estadual Paulista, Botucatu, SP, Brasil
}

Submitted: January 25, 2007; Returned to authors for corrections: May 19, 2007; Approved: July 04, 2008.

\begin{abstract}
Three compost formulations, consisting of two varieties of Cynodom dactylon (L.) Pers. (Coast-cross and Tyfton) and oat (Avena sativa) straw were tested for the cultivation of $A$. bisporus strains ABI-01/01, ABI$04 / 02$, ABI-05/03, and ABI-06/04. A completely randomized experimental design in a factorial scheme was adopted, with 12 treatments ( $4 \mathrm{~A}$. bisporus strains $\times 3$ types of compost) and 8 replicates. Each experimental unit corresponded to one box containing $12-12.5 \mathrm{~kg}$ fresh wet compost. The data were submitted to analysis of variance and the means were compared by Tukey test. According to the results, productivity of mushrooms was influenced by strain and/or compost type. It was also verified that crude protein, ash, and crude fiber contents in the mushroom varied with A. bisporus strain and straw used in the formulation of the compost.
\end{abstract}

Key-words: Agaricus bisporus, strains, straw, nutritional composition, productivity.

\section{INTRODUCTION}

The formulation of compost is crucial to carry on composting for Agaricus sp and it is essential to an adequate balance between nutrients, especially carbon and nitrogen (21). As a result, mycelium growth can be influenced by a reduction or excess concentration of nutrients, accumulation of toxic products, production of secondary metabolites, and changes in factors such as $\mathrm{pH}$, which consequently can influence the mushroom production $(2,14,15)$.

Several formulations can be used for production of Agaricus sp. which are usually determined by the availability and cost of substrates (16). Straws (rice, wheat, oat and barley), by-products (sugarcane bagasse), horse and chicken manure are the most important components used as lignocellulosic sources in composts $(11,12)$. However, due to a limited availability of horse manure in large amounts around the world, composts referred to as "synthetic" have been increasingly used, whose formulations are prepared without the addition of it (7).
Straw of cereals are used in most countries as a basic material for composts and wheat straw is commonly used in Europe and the United States (5) while rice straw is largely used in Asian countries (6).

In Brazil, wheat, rice, brachiaria, coast-cross, tyfton, barley straw have been used as substrates in formulations for composts of Agaricus sp (11). In some regions of São Paulo State, suppliers of straw (e.g. coast-cross, tyfton and Brachiaria sp.) provide in a very accessible price that are not sold because of their low quality standards for animal feed but still in a good quality for composting of mushroom cultivation. Usually supplying substrates for mushroom composts vary according to availability during the seasons of the year.

However, few scientific studies have compared the effectiveness of these substrates on the productivity of $A$. bisporus strains, where inconsistent information about advantages in using specific straws for mushroom compost are provide through mushroom farmers.

*Corresponding Author. Mailing address: Departamento de Produção Vegetal, FCA - UNESP. Fazenda Lageado, Caixa Postal 237. Rua José Barbosa de Barros, 1780. CEP 18603-970. Botucatu, SP, Brasil. Telephone +55 14 3811-7213. Fax: +55 14 3811-7206. E-mail: modcogumelo@fca.unesp.br 
Many edible mushrooms constitute a high-quality food, and are rich in proteins, chitin, vitamins, and minerals, and poor in calories and fat $(9,13$, and 20). However, the nutritional composition of mushrooms varies depending on the species, strain, processing and development stage of the mushrooms $(9,10)$.

Thus, this study aimed to characterize the nutritional composition of mushroom from A. bisporus strains cultivated in composts prepared with three different straws as well as to evaluate the productivity and biological efficiency.

\section{MATERIALAND METHODS}

The experiment was carried out in the facilities of Módulo de Cogumelos (Mushroom Research Center), Faculdade de Ciências Agronômicas (College of Agronomic Sciences), UNESP (São Paulo State University), Botucatu/ SP, Brazil.

\section{Spawn production}

The study was carried out with four strains from commercial cultivations maintained in the Culture Collection of the Mushroom Center of FCA/UNESP. Strains ABI-01/01 (medium size, white, steam thin and long, precocious opening cap, isolated in Mogi das Cruzes/SP), ABI-04/02 (medium size, white, high productivity, provided by Brasmicel-Mogi das Cruzes/ SP; ABI05/03 (medium-big size, white, isolated from Cabriúva/ SP); and ABI-06/04 (medium size, white, summer strain, producing up $20-22^{\circ} \mathrm{C}$, isolated from Itú/ SP). They were stocked in tubes with $\mathrm{CA}$ (compost-agar) medium submerged in sterilized mineral oil and preserved at $8^{\circ} \mathrm{C}$.

Initially, disks of the mother spawn were transferred to Petri dishes with CA medium under aseptic conditions; after inoculation, the Petri dishes were transferred to an incubator and kept for 25 days at $22 \pm 1^{\circ} \mathrm{C}$ for colonization. They were transferred to flasks with sorghum grains (400g), gypsum, and calcium carbonate. The grains were initially boiled in water for 40 minutes. After draining the excess water, $20 \mathrm{~g} \mathrm{~kg}^{-1}$ calcium carbonate and $160 \mathrm{~g} \mathrm{~kg}^{-1}$ gypsum were added (d.w). The bottom part of the flask lid was fitted with a paper filter. The bags were incubated at $22 \pm 1^{\circ} \mathrm{C}$ for 20 days. The spawn was produced by placing the substrate in high-density polyethylene bags (HDPE), using about $1200 \mathrm{~g}$ of grains per bag. The bags contained Tyvek $^{\circledast}$ tag in their upper part, thus allowing gas exchanges. In both cases, the substrates were autoclaved at $121^{\circ} \mathrm{C}$ for 3 hours. After incubation at $22 \pm 1^{\circ} \mathrm{C}$ for 30 days, the substrates were already colonized by the fungus, being thus referred to as spawn, and were then ready to be inoculated into the compost. The substrates used for the composts were analyzed at FCA/UNESP Fertilizers Laboratory and three types of compost were formulated, consisting of coast-cross, tyfton or oat straw in order to obtain a initial C/N ratio of 25/1 (Table 1).
Table 1. Formulation of composts prepared with coast-cross, tyfton, or oat straw.

\begin{tabular}{|c|c|c|c|c|c|c|}
\hline \multirow{3}{*}{ Ingredients, $\mathrm{kg}$} & \multicolumn{6}{|c|}{ Compost } \\
\hline & \multicolumn{2}{|c|}{ Coast-cross } & \multicolumn{2}{|c|}{ Tifton } & \multicolumn{2}{|c|}{ Oat } \\
\hline & FW & DW & FW & DW & FW & DW \\
\hline Sugarcane bagasse & 600.0 & 300.0 & 600.0 & 300.0 & 600.0 & 300.0 \\
\hline Coast-cross straw & 280.0 & 252.0 & & & & \\
\hline Tifton straw & & & 280.0 & 243.6 & & \\
\hline Oat straw & & & & & 280.0 & 243.6 \\
\hline Soybean meal & 100.0 & 90.0 & 90.0 & 81.0 & 100.0 & 90.0 \\
\hline Urea & 4.0 & 4.0 & 4.0 & 4.0 & 4.0 & 4.0 \\
\hline Weight of compost, $\mathrm{kg}$ & 984.0 & 646.0 & 974.0 & 628.6 & 984.0 & 637.6 \\
\hline Initial carbon, $\mathrm{kg}$ & & 318.1 & & 318.1 & & 321.4 \\
\hline Initial nitrogen, $\mathrm{kg}$ & & 12.5 & & 12.8 & & 12.6 \\
\hline Initial C/N ratio & & 25.4 & & 24.9 & & 25.6 \\
\hline
\end{tabular}

*FW= fresh weight and DW= dry weight.

Composting phase I was performed on concrete floor, open sides and natural ventilation. Before forming the windrows, all straw types were moistened and turned every day for a total period of 8 days. The windrows were formed pilling a straw layer ( $20 \mathrm{~cm}$ in height), followed by a sugarcane bagasse layer (20 cm in height) and built into a $1.8 \mathrm{~m}$ height $\times 1.8 \mathrm{~m}$ width. Urea and soybean meal were added equitably to the windrow. The composts were turned each other day, and water was added manually, with a hose, to maintain the moisture in $70-75 \%$. In all, 5 turnings were performed, totaling 12 days in Phase I. In phase II, the composts were transferred to perforated plastic boxes, measuring $56.5 \times 46.5 \times 28.5 \mathrm{~cm}$ (length, width, and height). The boxes were randomly arranged inside a chamber (Dalsem mushrooms) for pasteurization (6 hours at $61 \pm 1^{\circ} \mathrm{C}$ ) and conditioning $\left(11\right.$ days at $\left.48 \pm 1^{\circ} \mathrm{C}\right)$. At the end of phases I and II, three samples of each compost were collected and dehydrated at $65^{\circ} \mathrm{C}$ for 48 hours for analyses of carbon and nitrogen and $\mathrm{pH}$. Results are shown in Table 2.

\section{Inoculation and spawning run}

Inoculation of the composts were made manually, by adding $1.5 \mathrm{~g}$ of A. bisporus spawn per kilogram f.w. compost. To accomplish this, the composts were apportioned and transferred to other smaller polyethylene boxes ( $12-12.5 \mathrm{~g}$ of f.w. compost) internally lined with clear polyethylene plastic film containing holes on the bottom. The boxes were randomly arranged in an incubator (Dalsem Mushroom) and kept for 13 days at $22 \pm 1^{\circ} \mathrm{C}$. A loamy oxisol-alfisol from Fazenda Lageado (FCA/UNESP) was used as casing soil. The soil $\mathrm{pH}$ was corrected to 7.0 by adding calcium carbonate $\left(30 \mathrm{~kg} \mathrm{~m}^{-3}\right) 20$ days before casing. The soil was moistened to $60 \%$. $30 \%$ wood charcoal (1 to $2 \mathrm{~cm}$ thick) 
Table 2. Moisture, carbon, and nitrogen contents, $\mathrm{C} / \mathrm{N}$ ratio, and $\mathrm{pH}$ of composts prepared with coast-cross, tyfton, or oat at the end of composting phases I and II.

\begin{tabular}{|c|c|c|c|}
\hline & \multicolumn{3}{|c|}{ Compost } \\
\hline & Coast-cross & Tifton & Oat \\
\hline & \multicolumn{3}{|c|}{ End of phase I } \\
\hline$M^{*}$ & 71.10 & 71.13 & 74.74 \\
\hline $\mathrm{C}$ & 44.33 & 44.67 & 44.67 \\
\hline $\mathrm{N}$ & 2.48 & 2.05 & 2.18 \\
\hline $\mathrm{C} / \mathrm{N}$ & 17.85 & 21.82 & 20.46 \\
\hline \multirow[t]{2}{*}{$\mathrm{pH}$} & 6.27 & 6.00 & 6.13 \\
\hline & \multicolumn{3}{|c|}{ End of phase II } \\
\hline$M^{*}$ & 69.20 & 71.52 & 70.70 \\
\hline $\mathrm{C}$ & 40.33 & 40.33 & 43.33 \\
\hline $\mathrm{N}$ & 2.24 & 2.17 & 2.44 \\
\hline $\mathrm{C} / \mathrm{N}$ & 17.98 & 18.59 & 17.74 \\
\hline $\mathrm{pH}$ & 6.60 & 6.83 & 6.60 \\
\hline
\end{tabular}

$* \mathrm{M}=$ moisture $\mathrm{C}=$ carbon; $\mathrm{N}=$ nitrogen.

were added and pasteurization was carried out at $62^{\circ} \mathrm{C}$ for 8 hours, in a Dalsem Mushrooms container. Each box received about $15 \mathrm{~kg}$ of casing soil ( $4 \mathrm{~cm}$ height) and watered to keep in $70 \%$ of moisture. The compost was covered with a transparent plastic, placed in darkness and incubated for 15 days at $22 \pm 1^{\circ} \mathrm{C}$. After the casing soil was colonized, the plastics were removed and maintained temperature at $22 \pm 1^{\circ} \mathrm{C}$ and relative humidity between 75 and $85 \%$.

\section{Variables analyzed}

Number and fresh weight of mushroom: The number (NM) and fresh weight of mushroom (FWM) were determined daily during the harvesting.

Productivity and biological efficiency: Productivity $(\mathrm{P})$ was expressed as fresh weight of mushrooms (FWM)/fresh weight of compost (FWC) $x 100$ and biological efficiency (BE\%) as the fresh weight of mushrooms (FWM)/dry weight of compost (DWC) $x$ 100. The FWM was determined at the end of the harvesting and FWC was determined at the end of phase II.

\section{Nutritional analysis of mushroom from $A$. bisporus strains:}

The nutritional analyses of the mushroom were performed at Faculdade de Medicina Veterinária e Zootecnia - FMVZ/ UNESP's Bromatology Laboratory, Botucatu-SP. Two samples of dehydrated mushroom were collected at the $1^{\text {st }}$ flush and were determined crude protein, fat, ash, and crude fiber contents, according to Silva and Queiroz (18).

\section{Experimental Design and Statistical Analysis}

A completely randomized experimental design in a factorial scheme was adopted, with 12 treatments ( 4 A. bisporus strains $\times 3$ types of compost) and 8 replicates. The data were submitted to analysis of variance and the means were compared by Tukey test (19), using the Sisvar 4.2 statistical program, developed by Department of Mathematical Sciences from UFLA (Federal University of Lavras), MG.

\section{RESULTS AND DISCUSSION}

According to Table 3, there was an effect of strain, straw and of the strain $\times$ straw interaction for the biological efficiency. However, for productivity and fresh weight of mushroom there was an effect of straw and of the strain $\times$ straw interaction. Only a straw effect was observed for number of mushroom.

The values for number and weight of mushroom, productivity, and biological efficiency of $A$. bisporus strains ABI-05/03, ABI-06/04, ABI-04/02, and ABI-01/01 are shown in Table 4. The number of mushroom in composts derived from coast-cross and oat straw did not vary with $A$. bisporus strain. For the tyfton compost, however, strain ABI-04/02 was poorer than strain ABI-01/01. With regard to number of mushroom, there was no compost effect in strains ABI-06/04 and ABI-01/ 01 . On the other hand, strain ABI-05/03 produced a smaller number of mushrooms when grown in tyfton compost as compared to the oat compost. A similar fact occurred with strain ABI-04/02, which produced significantly poorer results when cultivated in tyfton compost as compared with the oat and coastcross composts.

With regard to fresh weight of mushrooms according to strains, there was no significant difference between strains when inoculated in coast-cross and oat composts (Table 4). On the other hand, when grown in the tyfton compost, strain ABI-04/ 02 was significantly poorer than strain ABI-01/01.

Table 3. F values obtained in the analysis of variance for number of mushroom (NM), fresh weight of mushroom (FWM), productivity (P), and biological efficiency (BE) of Agaricus bisporus strains ABI-05/03, ABI-06/04, ABI-04/02, and ABI-01/ 01 , cultivated in three different composts prepared with coastcross, tyfton, or oat straw.

\begin{tabular}{lllll}
\hline Causes of variation & \multicolumn{1}{c}{ NM } & FWM & \multicolumn{1}{c}{ P } & BE \\
\hline Strain $(\mathrm{St})$ & $2.19 \mathrm{~ns}$ & $2.60 \mathrm{~ns}$ & $2.66 \mathrm{~ns}$ & $2.73^{*}$ \\
Straw (S) & $7.79^{* *}$ & $6.76^{* *}$ & $6.96^{* *}$ & $5.05^{* *}$ \\
St x S & $1.62 \mathrm{~ns}$ & $2.33^{*}$ & $2.33^{*}$ & $2.40^{*}$ \\
CV \% & 35.48 & 33.05 & 32.87 & 32.97 \\
\hline
\end{tabular}

$* *$ significance $<1 \%$ level, *significance $<5 \%$ level, ns: not significantly different. CV\%: coefficient of variation. 
Table 4. Total mean values for number and fresh weight of mushroom, productivity, and biological efficiency of Agaricus bisporus strains ABI-05/03, ABI-06/04, ABI-04/02, and ABI-01/ 01 depending on the straw type used in the compost.

\begin{tabular}{|c|c|c|c|}
\hline \multirow{2}{*}{ Strains } & \multicolumn{3}{|c|}{ Straw } \\
\hline & Coast-cross & Tyfton & Oat \\
\hline & \multicolumn{3}{|c|}{ Number of mushrooms } \\
\hline ABI-05/03 & $183 \mathrm{Aab}^{*}$ & $140 \mathrm{AB} \mathrm{b}$ & $232 \mathrm{Aa}$ \\
\hline ABI-06/04 & $236 \mathrm{Aa}$ & $161 \mathrm{AB} a$ & $194 \mathrm{Aa}$ \\
\hline ABI-04/02 & $190 \mathrm{Aa}$ & $96 \mathrm{Bb}$ & $208 \mathrm{Aa}$ \\
\hline \multirow[t]{2}{*}{ ABI-01/01 } & $203 \mathrm{Aa}$ & $210 \mathrm{Aa}$ & $225 \mathrm{Aa}$ \\
\hline & \multicolumn{3}{|c|}{ Fresh weight of mushrooms (g) } \\
\hline ABI-05/03 & $1723.8 \mathrm{Aab}$ & $1219.3 \mathrm{ABb}$ & $1898.3 \mathrm{Aa}$ \\
\hline ABI-06/04 & $2205.3 \mathrm{Aa}$ & $1572.1 \mathrm{ABa}$ & $1680.8 \mathrm{Aa}$ \\
\hline ABI-04/02 & $1637.4 \mathrm{Aa}$ & $851.9 \mathrm{Bb}$ & $1829.9 \mathrm{Aa}$ \\
\hline \multirow[t]{2}{*}{ ABI-01/01 } & $1662.3 \mathrm{Aa}$ & $1871.4 \mathrm{Aa}$ & $1906.3 \mathrm{Aa}$ \\
\hline & \multicolumn{3}{|c|}{ Productivity (\%) } \\
\hline ABI-05/03 & $14.0 \mathrm{Aab}$ & $9.8 \mathrm{AB} \mathrm{b}$ & $15.4 \mathrm{Aa}$ \\
\hline ABI-06/04 & $18.0 \mathrm{Aa}$ & $12.8 \mathrm{AB} \mathrm{a}$ & $13.8 \mathrm{Aa}$ \\
\hline ABI-04/02 & $13.3 \mathrm{Aa}$ & $7.0 \mathrm{~B} \mathrm{~b}$ & $15.0 \mathrm{Aa}$ \\
\hline \multirow[t]{2}{*}{ ABI-01/01 } & $13.6 \mathrm{Aa}$ & 15.3 A a & $15.5 \mathrm{Aa}$ \\
\hline & \multicolumn{3}{|c|}{ Biological efficiency (\%) } \\
\hline ABI-05/03 & $45.3 \mathrm{Aa}$ & $34.5 \mathrm{AB} \mathrm{a}$ & $52.5 \mathrm{Aa}$ \\
\hline ABI-06/04 & $58.3 \mathrm{Aa}$ & $44.9 \mathrm{Aa}$ & $47.2 \mathrm{Aa}$ \\
\hline ABI-04/02 & $43.3 \mathrm{Aa}$ & $24.4 \mathrm{~B} \mathrm{~b}$ & $51.2 \mathrm{Aa}$ \\
\hline ABI-01/01 & $44.1 \mathrm{~A} \mathrm{a}$ & $53.4 \mathrm{Aa}$ & $52.9 \mathrm{Aa}$ \\
\hline
\end{tabular}

*Means followed by the same upper case letters within a column and lower case letters within a row are not significantly different (Tukey, $5 \%$ ).

There was no compost type effect on fresh weight of mushroom for strains ABI-06/04 and ABI-01/01. Strain ABI-05/ 03 , however, had a poorer performance when cultivated in the tyfton compost when compared with the oat compost. Finally, strain ABI-04/02 produced a significantly lower result when grown in the tyfton compost as compared with the results obtained in the oat and coast-cross straw composts. Dias et al. (3) analyzed the production of Pleurotus sajor-caju in different agricultural residues (bean straw corn straw and coffee hulls) and also observed mycelium growth, production, and biological efficiency differences depending on the compost used.

Comparing the productivity of the strains on composts, it was observed that significant differences existed between strains in the coast-cross and oat composts. In the tyfton compost, strain ABI-04/02 was poorer than strain ABI-01/01. There was no compost type effect on productivity for strains ABI-06/04 and ABI-01/01 (Table 4). On the other hand, strain ABI-05/03 produced a significantly lower result when grown in the tyfton compost as compared with the results obtained in the oat compost. A similar fact occurred with strain ABI-04/02, which gave significantly lower results when inoculated in the tyfton compost as compared with the oat and coast-cross composts.

The biological efficiency of $A$. bisporus strains in the coastcross and oat composts could not be discriminated. Strain ABI04/02 inoculated in the tyfton compost, however, had a significantly lower value in relation to strains $\mathrm{ABI}-06 / 04$ and ABI-01/01 (Table 4). In comparing the performance of each strain in the different types of composts tested, it was observed that the performances of strains $\mathrm{ABI}-05 / 03, \mathrm{ABI} 06 / 04$, and ABI-01/ 01 were the same in the three types of composts. Nevertheless, strain ABI-04/02 had a significantly poorer result when cultivated in the tyfton compost.

Table 5 presents the $\mathrm{F}$ values obtained in the analysis of variance for crude protein, fat, ash, and crude fiber of Agaricus bisporus strains ABI-05/03, ABI-06/04, ABI-04/02, and ABI-01/ 01 cultivated in the three types of composts. There were effects of strain, straw and of the line $\times$ straw interaction on variables crude protein, ash, and crude fiber. However, there was no effect of the factors and of the interaction between them on fat.

The crude protein, fat, ash, and crude fiber values for Agaricus bisporus strains ABI-05/03, ABI-06/04, ABI-04/02, and ABI-01/01 are displayed in Table 6 . In regard to crude protein content, all A. bisporus strains in the coast-cross straw compost were different among themselves. The best performance was achieved by strain ABI-04/02 and the poorest by strain ABI-01/ 01 . In the tyfton straw compost, however, crude protein content was inferior in strain ABI-01/01 in relation to the other strains, which were similar among themselves. Finally, when grown in the oat compost, the best performance was observed for strain ABI-04/02 and the poorest for strain ABI-01/01. On the other hand, in comparing crude protein content for the various

Table 5. F values obtained in the analysis of variance for crude protein, fat, ash, and crude fiber of Agaricus bisporus strains ABI-05/03, ABI-06/04, ABI-04/02, and ABI-01/01, cultivated in three types of composts prepared from coast-cross, tyfton, or oat straw.

\begin{tabular}{ccccc}
\hline $\begin{array}{c}\text { Causes of } \\
\text { variation }\end{array}$ & $\begin{array}{c}\text { Crude } \\
\text { Protein }\end{array}$ & Fat & Ash & $\begin{array}{c}\text { Crude } \\
\text { fiber }\end{array}$ \\
\hline Strain (St) & $173.85^{* *}$ & $0.54 \mathrm{~ns}$ & $44.48^{* *}$ & $43.17^{* *}$ \\
Straw (T) & $14.03^{* *}$ & $3.73 \mathrm{~ns}$ & $11.21^{* *}$ & $21.75^{* *}$ \\
Sx T & $19.59^{* *}$ & $0.60 \mathrm{~ns}$ & $4.41^{*}$ & $8.60^{* *}$ \\
CV\% & 1.65 & 18.00 & 1.69 & 4.92 \\
\hline
\end{tabular}

$* *$ significance $<1 \%$ level; * significance $<5 \%$ level; ns: not significantly different; $\mathrm{CV} \%$ : coefficient of variation. 
compost types, strains ABI-05/03 and ABI-04/02 gave the best performances when grown in the coast-cross compost. Strains ABI-06/04 and ABI-01/01, however, showed the best results when cultivated in the tyfton compost (Table 6).

As to fat, which varied from 1.90 to $3.06 \%$, there was no difference due to strains or straw types.

With regard to ash content, strain ABI-01/01 had the poorest performance in relation to the others when cultivated in the coast-cross and oat composts. A similar result also occurred when this strain was cultivated in the tyfton compost, with the poorest performance when compared with strains ABI-06/04 and ABI-04/02. There was no compost type effect on ash content for strain ABI-05/03. Strains ABI-06/04 and ABI-01/01, however, had the poorest result when grown in the oat compost, as compared with the tyfton compost. Finally, strain ABI-04/02 obtained the poorest performance when cultivated in the coastcross compost in relation to the tyfton compost.

Table 6. Mean crude protein, fat, ash, and crude fiber content values for Agaricus bisporus strains ABI-05/03, ABI-06/04, ABI-04/02, and ABI-01/01 in different compost types.

\begin{tabular}{|c|c|c|c|}
\hline \multirow[b]{2}{*}{ Strains } & \multicolumn{3}{|c|}{ Type of compost } \\
\hline & Coast-cross & Tifton & Oat \\
\hline & \multicolumn{3}{|c|}{ Crude Protein $(\%)$} \\
\hline ABI-05/03 & $36.17 \mathrm{~B} \mathrm{a}^{*}$ & $34.36 \mathrm{Ab}$ & $34.30 \mathrm{~B} \mathrm{~b}$ \\
\hline ABI-06/04 & $32.86 \mathrm{Cb}$ & $35.21 \mathrm{Aa}$ & $33.69 \mathrm{~B} \mathrm{~b}$ \\
\hline ABI-04/02 & $37.88 \mathrm{Aa}$ & $34.30 \mathrm{Ac}$ & $36.28 \mathrm{Ab}$ \\
\hline \multirow[t]{2}{*}{ ABI-01/01 } & $29.80 \mathrm{Db}$ & $31.37 \mathrm{~B} \mathrm{a}$ & $26.78 \mathrm{Cc}$ \\
\hline & \multicolumn{3}{|c|}{ Fat (\%) } \\
\hline ABI-05/03 & $2.33 \mathrm{Aa}$ & $2.05 \mathrm{Aa}$ & $2.34 \mathrm{Aa}$ \\
\hline ABI-06/04 & $2.36 \mathrm{Aa}$ & $2.34 \mathrm{Aa}$ & $2.64 \mathrm{Aa}$ \\
\hline ABI-04/02 & $2.36 \mathrm{Aa}$ & $2.17 \mathrm{Aa}$ & $3.06 \mathrm{Aa}$ \\
\hline \multirow[t]{2}{*}{ ABI-01/01 } & $1.90 \mathrm{Aa}$ & $2.23 \mathrm{Aa}$ & $2.86 \mathrm{Aa}$ \\
\hline & \multicolumn{3}{|c|}{ Ash (\%) } \\
\hline ABI-05/03 & $11.39 \mathrm{Aa}$ & $11.09 \mathrm{BCa}$ & $11.14 \mathrm{AB} a$ \\
\hline ABI-06/04 & $11.12 \mathrm{Aab}$ & $11.33 \mathrm{AB} \mathrm{a}$ & $10.71 \mathrm{Bb}$ \\
\hline ABI-04/02 & $11.02 \mathrm{Ab}$ & $11.77 \mathrm{Aa}$ & $11.36 \mathrm{Aab}$ \\
\hline \multirow[t]{2}{*}{ ABI-01/01 } & $10.31 \mathrm{~B} \mathrm{ab}$ & $10.60 \mathrm{Ca}$ & $9.83 \mathrm{Cb}$ \\
\hline & \multicolumn{3}{|c|}{ Crude Fiber $(\%)$} \\
\hline ABI-05/03 & $7.56 \mathrm{Ab}$ & $7.33 \mathrm{Ab}$ & $10.31 \mathrm{Aa}$ \\
\hline ABI-06/04 & $6.86 \mathrm{Aa}$ & 7.01 AB a & $7.42 \mathrm{~B} \mathrm{a}$ \\
\hline ABI-04/02 & $7.50 \mathrm{Aa}$ & $7.60 \mathrm{Aa}$ & $7.56 \mathrm{~B} \mathrm{a}$ \\
\hline ABI-01/01 & $5.64 \mathrm{~B} \mathrm{a}$ & $6.07 \mathrm{~B} \mathrm{a}$ & $6.57 \mathrm{~B} \mathrm{a}$ \\
\hline
\end{tabular}

*For each variable, means followed by the same upper case letters in each column and lower case letters in each row do not differ (Tukey, $5 \%)$.
In comparing the crude fiber content among the strains, strain ABI-01/01, cultivated in the coast-cross compost, gave the poorest result in relation to the other strains. A similar fact occurred in the tyfton compost, where this strain had an inferior performance than strains ABI-05/03 and ABI-04/02. Finally, in the oat compost, strain $\mathrm{ABI}-05 / 03$ had a superior result in relation to the other strains. On the other hand, in comparing crude fiber content for the various compost types, it was observed that strain $\mathrm{ABI}-05 / 03$ showed the best performance when cultivated in the oat compost. For strains ABI-06/04, ABI-04/02, and ABI$01 / 01$, however, crude fiber contents did not vary with compost (Table 6).

Maio et al. (8) studied the influence of substrate composition on the growth velocity of the mushroom Pleurotus ostreatus and observed a significant correlation between substrate formulation and the nutritional composition of the mushroom. Shibata and Demiate (17) evaluated the chemical composition of the mushroom Agaricus blazei and concluded that there are nutritional differences between the two A. blazei strains tested, with strain $\mathrm{AbM}$ being richer in fibers and minerals, while strain Jun-17 showed a higher carbohydrate content.

\section{RESUMO}

\section{Produção de quatro linhagens de Agaricus bisporus em três formulações de compostos e análises bromatológicas dos cogumelos produzidos}

Três formulações de composto, à base de palhas de Cynodom dactylon (L.) Pers. (cultivares Coast-cross e Tyfton) e Aveia-Avena sativa, foram testadas no cultivo das linhagens ABI-01/01, ABI-04/02, ABI-05/03 e ABI-06/04 de $A$. bisporus. O delineamento experimental foi em esquema fatorial, inteiramente casualizado com 12 tratamentos (4 linhagens de A. bisporus x 3 tipos de composto) e 8 repetições. Cada unidade experimental constou de uma caixa com 12-12,5 kg de composto fresco úmido. Os dados foram submetidos à análise de variância e as médias foram comparadas pelo teste de Tukey. De acordo com os resultados obtidos verificou-se que a produção de cogumelos foi influenciada pela linhagem e/ou pelo tipo de composto. Também verificou-se que o teor de proteína bruta, cinzas e fibra bruta de basidiomas variou com a linhagem de $A$. bisporus e com o tipo de palha utilizada na formulação do composto.

Palavras-chave: Agaricus bisporus, linhagens, palha, composição nutricional, produtividade.

\section{REFERENCES}

1. Bononi, V.L.; Capelari, M.; Trufem, S.F.B. (1995). Cultivo de cogumelos comestíveis. Ícone, São Paulo, 206p.

2. Diamantopoulou, P.; Philippoussis, A. (2001). Production attributes of Agaricus bisporus white and off-while strains and the effect of 
calcium chloride irrigation on productivity and quality. Sci. Hortic., 91, 379-391.

3. Dias, E.S.; Koshikimo, E.M.S.; Schwan, R.F.; Silva, R. (2003). Cultivo do cogumelo Pleurotus sajor-caju em diferentes resíduos agrícolas. Ciênc. Agrotec., 27 (6), 1363-1369.

4. Eira, A.F.; Minhoni, M.T.A. (1997). Manual teórico-prático do cultivo de cogumelos comestíveis. 2.ed. Fundação de Estudos e Pesquisas Agrícolas e Florestais, Botucatu, 115 p.

5. Gerrits, J.P.G. (1985). Developments in composting in the Netherlands. Mushroom J., 146, 45-53.

6. Kim, D.S. (1978). Cultivation in asian countries: growing in temerate zones. In: Chang, S.T., Hayes, W. A. (eds). The biology and cultivation of edible mushrooms. Academic Press, New York, USA, p. 345-62.

7. Kopytowski Filho, J. (2006). Produtividade e eficiência biológica de Agaricus blazei (Murrill) Heinemann, em diferentes condições de cultivo. Botucatu, Brasil, 134p. Thesis. Faculdade de Ciências Agronômicas, UNESP).

8. Maio, C.S.S.; Padilha, E.; Corrêa, F.V.; Costa, J.A.V. (2003). Influência da composição do substrato na velocidade de crescimento do cogumelo comestível Pleurotus ostreatus. XIV Simpósio Internacional de Fermentações. http://www.enq.ufsc.br/eventos/sinaferm/trabalhos completos/t218.doc

9. Manzi, P.; Aguzzi, A.; Pizzoferrato, L. (2001). Nutritional value of mushrroms widely consumed in Italy. Food Chem., Oxford, 73 (3), 321-325.

10. Menezes, M.C. (2005). Efeito do Agaricus blazei (Murrill) ss. Heinemann no estado nutricional e na bioquímica hepática em portadores de hepatite C. Botucatu, Brasil, 113 p. (Master. Thesis. Faculdade de Medicina de Botucatu, UNESP).
11. Minhoni, M.T.A.; Kopytowski Filho, J.; Andrade, M.C.N. (2005). Cultivo de Agaricus blazei Murrill ss. Heinemann. Fundação de Estudos e Pesquisas Agrícolas e Florestais, Botucatu, 141 p.

12. Peil, R.M.; Rosseto, E.A.; Rocha, M.T.R. (1995). Rendimento do cogumelo Agaricus bisporus (Lange) Imbach em três formulações de compostos. Rev. Bras. Agrociência, 1 (3), 163-166.

13. Ragunathan, R.; Swaminathan, K. (2003). Nutritional status of Pleurotus spp. grown on various agro-wastes. Food Chem., 80, 371-375.

14. Ramírez, L.; Muez, V.; Alfonso, M.; Barrenechea, A.G.; Alfonso, L.; Pisabarro. (2001). Use of molecular markers to differentiate between commercial strains of the button mushroom Agaricus bisporus. FEMS Microbiol. Lett., 198, 45-48.

15. Regina, M. (2001). Cinética do crescimento miceliano de Lentinula edodes (Berk.) Pegler em bagaço de cana-de-açúcar e serragem de eucalipto. Botucatu, Brasil, 87 p. (Master. Thesis. Faculdade de Ciências Agronômicas, UNESP).

16. Sánchez, J.E.; Royse, D.J. (2001). Adapting substrate formulas used for shiitake for production of brown Agaricus bisporus. Bioresour. Technol., 77, 65-69.

17. Shibata, C.K.R.; Demiate, I.M. (2003). Cultivo e análise da composição química do cogumelo do sol (Agaricus blazei Murril). Publ. UEPG Ci. Biol. Saúde, 9, 21-32.

18. Silva, D.J.; Queiroz, A.C. (2002). Análise de alimentos: métodos químicos e biológicos. UFV, Viçosa, $235 \mathrm{p}$.

19. Snedcon, G.W.E.; Cochran, W.G. (1972). Statistical methods. 6.ed. Press, The Iowa State University, $325 \mathrm{p}$.

20. Yang, J.; Lin, H.; Mau, J. (2002). Antioxidant properties of several commercial mushrooms. Food Chem., 77, 229-235.

21. Wood, D.A.; Smith, J.F. (1987). The cultivation of mushrooms. In: Norris, J.R., Pettipher, G.L. (eds). Essays in Agricultural and Food Microbiology. The Bath Press, Avon, p. 309-343. 